\title{
ANTICIPATION OF VERTEBRAL PEDICLE BREACH THROUGH DYNAMIC SURGICAL GUIDANCE
}

\author{
PREVISÃO DE ROTURA DO PEDÍCULO VERTEBRAL POR MEIO DE GUIA \\ CIRÚRGICO DINÂMICO
}

\author{
PREVISIÓN DE ROTURA DEL PEDÍCULO VERTEBRAL POR MEDIO DE GUÍA \\ QUIRÚRGICA DINÁMICA
}

John Williams ${ }^{1}$, Amer Samdani ${ }^{2}$, Helton Luiz Aparecido Defino ${ }^{3}$, Keri George ${ }^{4}$, John Gaughan ${ }^{5}$, Randal Betz ${ }^{2}$

\begin{abstract}
Objective: To determine the effectiveness of a pedicle probe to anticipate an impending breach and allow redirection during placement of a pilot pedicle hole. Methods: Purposely four cortical wall sites were drilled: medial and lateral pedicle wall, and lateral and anterior wall of the vertebral body. The surgeon stopped probing when the sound changed, suggesting abutment against the cortical wall ("anticipation" of impending breach). A fluoroscopy image was then obtained. The surgeon then advanced the PediGuard through the cortex until the sound changed, indicating a breach. In the second part of the study three probes were used: 1) DSG (PediGuard) with curved tip with electronics ON; 2) DSG with electronics OFF; 3) standard Lenke probe. After the images were taken, the operating surgeon (blinded to x-rays) was instructed to redirect and continue drilling into the vertebral body. Results: The surgeon accurately anticipated 60 of 75 (80\%) of the breaches, 17 of 19 (89\%) in the medial pedicle wall. In the second part of the study the DSG with electronics ON was superior to the DSG with electronics OFF as well as the standard Lenke probe $(100 \%$ vs. $90 \%$ vs. $79 \%, p=0.0191)$. Conclusion: Successful redirection by passing the pedicle probes into the vertebral body without a breach after anticipation of an impending pedicle wall breach occurred in $100 \%$ of the drillings when done with the DSG with the electronics ON vs only $84 \%$ when there was no electronic feedback.
\end{abstract}

Keyword: Spine; Electric Conductivity; Fluoroscopy.

\section{RESUMO}

Objetivo: Avaliar a efetividade da sonda pedicular para prever a rotura iminente e permitir o redirecionamento durante o posicionamento de orifício piloto no pedículo. Métodos: Intencionalmente, foram feitos quatro orifícios na parede cortical: parede medial e lateral do pedículo e parede lateral e anterior do corpo vertebral. O cirurgião parava a sondagem à mudança do som, que sugeria a proximidade da parede cortical ("previsão" de rotura iminente). A imagem por fluoroscopia era obtida. A seguir, o cirurgião avançava a sonda PediGuard através do osso cortical até a alteração do som, que indicava a rotura. Na segunda parte do estudo foram utilizadas três sondas: GCD (PediGuard) com ponta curva ligada, PediGuard curva desligada e sonda Lenke padrão. Depois que as radiografias eram feitas, o cirurgião (sem ver as imagens) era instruído a redirecionar e a continuar perfurando o corpo vertebral. Resultados: O cirurgião previu com precisão 60 das 75 (80\%) roturas, 17 de 19 (89\%) na parede medial do pedículo. Na segunda parte do estudo, o guia cirúrgico dinâmico ligado foi superior à desligado, assim como à sonda Lenke padrão (100\% vs. 90\% vs. 79\%, $p=0,0191)$. Conclusão: O redirecionamento bem-sucedido da sonda pedicular no interior do corpo vertebral, sem rotura devido à previsão de rotura iminente da parede do pedículo ocorreu em 100\% das perfurações com a utilização do o guia cirúrgico dinâmico com o dispositivo ligado, em comparação com 84\% das perfurações com o dispositivo desligado.

Descritores: Coluna vertebral; Condutividade elétrica; Fluoroscopia.

\section{RESUMEN}

Objetivo: Evaluar la efectividad de la sonda pedicular para prever la rotura inminente y permitir el redireccionamiento durante el posicionamiento de orificio piloto en el pedículo. Métodos: Intencionalmente, fueron hechos cuatro orificios en la pared cortical: pared medial y lateral del pedículo y pared lateral y anterior del cuerpo vertebral. El cirujano paraba el sondeo al cambiar el sonido, que sugería la proximidad de la pared cortical ("previsión" de rotura inminente). Era obtenida imagen por fluoroscopia. A seguir, el cirujano avanzaba la sonda PediGuard a través del hueso cortical hasta la alteración del sonido, que indicaba la rotura. En la segunda parte del estudio fueron utilizadas tres sondas: ECMT (PediGuard) con punta curva encendida, PediGuard curva apagada y sonda Lenke estándar. Después que las radiografías eran realizadas, el cirujano (sin ver las imágenes) era instruido a redireccionar y a continuar perforando el cuerpo vertebral. Resultados: El cirujano previno con precisión 60 de las 75 (80\%) roturas, 17 de 19 (89\%) en la pared medial del pedículo. En la segunda parte del estudio, la sonda ECMT encendida fue superior a la apagada, así como a la sonda Lenke estándar (100\% vs. 90\% vs. 79\%, $p=0,0191$ ). Conclusión: El redireccionamiento exitoso de la sonda pedicular en el interior del cuerpo vertebral, sin rotura debido a la previsión de rotura inminente de la pared del pedículo ocurrió en 100\% de las perforaciones con el uso de la sonda ECMT con el dispositivo encendido, en comparación con 84\% de las perforaciones con el dispositivo apagado.

\section{Descriptores: Columna vertebral; Conductividad eléctrica; Fluoroscopia.}

\footnotetext{
1. Parkview Hospital, Fort Wayne, IN, United States.

2. Shriners Hospitals for Children Philadelphia, Philadelphia, PA, United States.

3. Faculdade de Medicina de Ribeirão Preto, Universidade de São Paulo, SP, Brazil.

4. SpineGuard, Inc., San Francisco, CA, United States.

5. Temple University School of Medicine, Philadelphia, PA, United States.
}

Study conducted at Vegas Lab, MedCure 2455W Horizon Ridge Pkwy, Henderson, NV, 89052, United States.

Correspondence: Helton L. A. Defino. Av. Bandeirantes, 3900, $11^{\circ}$ andar, Monte Alegre, Ribeirão Preto, SP, Brazil. hladefin@fmrp.usp.br 


\section{INTRODUCTION}

Pedicle screw fixation has been shown to be superior to other methods of instrumentation of the spine for spinal fusion and correction of spine deformity. ${ }^{1-6}$ In a meta-analysis of the literature by Yahiro $^{7}$ of 5,756 patients reported in 101 articles, the success of fusions with pedicle screws was $94.8 \%$, attesting to the clinical usefulness of pedicle screw instrumentation. However, one of the complications of pedicle screw placement is pedicle perforation. Perforation rates range from 2.5 to $40 \%$. $^{1,2,8,9}$ In 2001 , Belmont et al. ${ }^{1}$ reported medial breeches in thoracic screw placement of $14 \%$ and lateral breeches of $29 \%$.

Perforations can further lead to complications such as dural tear, ${ }^{9}$ nerve root injuries, ${ }^{9}$ paraplegia, ${ }^{9-12}$ or vascular injury. ${ }^{13}$ In a large series of 2,187 patients with degenerative spondylolisthesis, ${ }^{3} 5 \%$ had intraoperative adverse events associated with the technical aspects of screw insertion. Nerve root injury, spinal cord injury, and vascular injury occurred in $1 \%$ of patients. Radicular pain occurred in $1.5 \%$ of patients, and dural tears occurred in $0.5 \%$. In a meta-analysis of the literature ${ }^{7}$ of 5,756 patients reported in 101 articles, there were 65 dural tears (1.1\%) and 99 neural injuries (1.7\%).

Bolger et al. ${ }^{14}$ reported 147 manual pedicle drillings performed in 11 hospitals during 28 spinal surgeries between September 2002 and March 2003. A total of 23 vertebral cortex perforations out of the 147 manual pedicle drillings (16\%) were confirmed, 22 of which $(95.7 \%)$ were detected by the PediGuard during the procedure. A total of 12 vertebral cortex perforations (52.2\%) were detected by the PediGuard but not by the physician, while only one vertebral cortex perforation (4.3\%) was detected by the physician but not by the PediGuard.

The focus of the above study by Bolger et al. ${ }^{14}$ was to analyze breeches during the pilot hole preparation, but the study did not address one of the best uses of PediGuard: the anticipation of breech. This has led to the purpose of this current study: to determine the relative effectiveness of the PediGuard for anticipation of impending breaches during drilling of a pilot pedicle screw hole in the thoracic and lumbar spine.

One of the unique characteristics of the PediGuard through its impedance reading across the tip is the ability to detect change in tissue density. There is a clear and definable gradient between cancellous bone and cortical bone; therefore, when the tip of the PediGuard probe is up against the cortex, the sound changes significantly, thereby warning the surgeon of impending drilling through the pedicle wall or the vertebral body cortex. This anticipation mode of the PediGuard takes place before there is an actual complete breach of the cortex by the pedicle probe. If this occurs before the tip of the probe is outside of the pedicle wall, then EMG signaling (if medial) will not detect this impending breach. In addition, because there is not an actual hole through the cortex, manual probing with a ball tip feeler will not detect this, nor will fluoroscopy detect an impending breach, only a probe tip that has gone through the cortical wall. The navigation component of the O-arm may possibly attempt to prevent breach; however, there is a known 3-4mm error in navigation accuracy. ${ }^{7}$ With CT guided navigation, the only way to confirm for sure if there is a breach is to shoot another image, therefore increasing the radiation exposure to both patient and surgeon.

Therefore, the PediGuard device is the only device that could dynamically (in real time) prevent the surgeon from breaching the pedicle wall cortex or the vertebral body cortex before actually pushing the probe through the cortex.

The purpose of this study is to determine the effectiveness of anticipating an impending breach of the pedicle wall or vertebral body during placement of a pilot (drill) hole in a cadaver saline model. In the second part of the study, the surgeon uses the same probe with a curved tip to determine the effectiveness in guiding redirection of the drilling after anticipation of an impending breach.

\section{METHODOLOGY}

A cadaver model (saline soaked spine) was used for this study. All cadaver specimens were young, male with no tumor history. The cadaver specimen was prepared specifically for this study as follows: Removal of all soft tissue from the external aspect of the cadaver spine to allow for accurate inspection of the external lateral surfaces of the pedicle and vertebral body for visual confirmation of a pedicle probe breech A total laminectomy of the anticipated levels of the thoracic and lumbar spine to be probed during the study was performed. Removal of the spinal cord in the thoracic spine beneath the laminectomy and the caudal equina in the lumbar spine (this is done to provide clear visualization of the medial, superior, and inferior wall of the pedicle for visual confirmation of the breach).

The surgeon then used fluoroscopy to find starting points over the pedicles in the thoracic and lumbar spine. The surgeon then commenced drilling purposefully planning for a pedicle or vertebral body wall breach.

The PediGuard changes sound (frequency and pitch) to differentiate cancellous bone from cortical bone from saline (indicating breach). The surgeon stopped probing when the sound changed, suggesting abutment against the cortical wall ("anticipation" of impending breach.)When the PediGuard detects a cortical wall "anticipation" (impending breach), the surgeon reported to the data collector his/her clinical sense of the position of the pedicle probe; either pedicle wall (medial, lateral, or vertebral body wall (anterior or lateral) A fluro image was then performed

After the surgeon obtains the fluoroscopy the surgeon then finished drilling with the pedicle probe in the same direction and performed a breach.

Prior to advancing the probe thru the cortex a measurement with a plastic ruler was made and photographed before advancing the probe thru the cortex After the surgeon advanced the PediGuard in the same direction until a breach sound is confirmed. a new measurement was made and documented with a picture Visual confirmation by the surgeon to confirm a breach.

In part 2 of the study: Three probes were used in the study: 1) Dynamic surgical guidance (PediGuard) with curved tip with electronics $\mathrm{ON}$, which changes sound to differentiate cancellous from cortical from saline; 2) DSG with electronics OFF; 3) standard Lenke probe. Two operating surgeons purposely placed the tip of the probe on the medial or lateral pedicle cortex (simulating an impending pedicle wall breach) based on a randomization schedule. After the images were taken, the operating surgeon (blinded to x-rays) was instructed to redirect and continue drilling into the vertebral body. Two operating surgeons experienced with use of these probes were instructed to purposely place the tip of the probe on the medial or lateral pedicle cortex (simulating an impending pedicle wall breech) based on the randomization schedule.

The probe depth had to at $5 \mathrm{~mm}-15 \mathrm{~mm}$ so as to assure position within the pedicle. Once the probe was docked on the medial or lateral pedicle wall an AP and lateral fluoroscopy $x$-ray were taken. The operating surgeon did not look at the images the images were accessed later independently to confirm impending breech.

After the images were taken the operating surgeon was instructed to commence drilling The surgeon's goal was to safely and accurately advance the probe off of the medial or lateral cortex without breaching while advancing the probe to a total depth into the vertebral body to at least $30 \mathrm{~mm}$ in the thoracic and $35 \mathrm{~mm}$ in the lumbar spine. Another AP and lateral fluoroscopy x-ray was taken.

\section{Outcome measurements included}

Surgeon's clinical sense of the pedicle probe tip position Pedicle wall impending breach - medial, lateral, or. Vertebral body cortex anterior or lateral.

Intraoperative fluoro images as to confirm Cortical position of pediGuard tip medial, lateral pedicle wall or Vertebral body cortex - anterior or lateral.

Direct visualization confirmed the breach and an additional 
measurement quantified the "anticipation" of the breach (1-5 mm was chosen as the criterion for accurate breach "anticipation").

For part 2: Successful rediredtion was defined as passing the pedicle probes into the vertebral body without a breech after docking in the pedicle.

\section{Statistical Analysis}

Frequencies and percentages of successful and unsuccessful cortex anticipation are presented along with confidence intervals where appropriate.

\section{RESULTS}

\section{In part 1 the anticipation study}

Seventy-five total pedicle drillings were performed on two cadavers. The surgeon reported "successful" breach anticipation in 65 of the $75(87 \%)$ drillings, This included 19 of $19(100 \%)$ in the medial pedicle wall, 18 of $18(100 \%)$ in the lateral pedicle wall, 13 of $18(72 \%)$ in the anterior vertebral body and 15 of $19(79 \%)$ in the lateral vertebral body.

In an additional 10 drillings (13\%), the surgeon correctly detected a breach but not the anticipation, which would have allowed earlier redirection of the drilling.

Subsequent analysis of 70 AP fluoroscopy films by a different surgeon, was performed. Five films were unusable. Results indicated that 61 of $70(87 \%)$ PediGuard placements were in or touching the cortex. This included 18 of 19 (95\%) in the medial pedicle wall, 18 of $18(100 \%)$ in the lateral pedicle wall, 13 of $16(81 \%)$ in the anterior vertebral body and 12 of $17(71 \%)$ in the lateral vertebral body.

Pre-and post-breach measurements (in $\mathrm{mm}$ ) indicated that 60 of $65(92 \%)$ breach measurements were within the pre-specified range of $1-5 \mathrm{~mm}$ of accurate breach anticipation, 17 of $19(89 \%)$ in the medial pedicle wall, 15 of $17(88 \%)$ in the lateral pedicle wall, 13 of $13(100 \%)$ in the anterior vertebral body and 15 of $16(94 \%)$ in the lateral vertebral body. Measurements were not recorded in 10 drillings.

The sensitivity of PediGuard to detect cortex before a breach compared to fluoroscopy is shown in Table 1.

Table 1. Sensitivity to detect a cortical breach.

\begin{tabular}{c|c|c|c|c|c|c}
\hline \multirow{2}{*}{} & \multicolumn{3}{|c|}{ Pedicle drillings } & \multicolumn{3}{c}{ Vertebral body drillings } \\
\cline { 2 - 7 } & $\%$ & $\#$ & $95 \% \mathrm{Cl}$ & $\%$ & $\#$ & $95 \% \mathrm{Cl}$ \\
\hline PediGuard & $97 \%$ & $35 / 36$ & $83.8-97.2 \%$ & $84 \%$ & $21 / 25$ & $63.1-94.8 \%$ \\
\hline
\end{tabular}

\section{Part 2 Redirectionality}

Successful rediredtion was defined as passing the pedicle probes into the vertebral body without a breech after docking in the pedicle. Analysing the 92 drillings of the surgeons PediGuard with electronics was superior to PediGuard without electronics and the standard Lenke probe (100\% vs. 90\% vs. $79 \%$ ), $p=0.0191$. When the results of the instruments were combined comparing electronics on vs eletronic off, PediGuard with electronics had a vertebral body breach rate of $0 \%$ compared to no electronics, $16 \%$, $p=0.0243$. These results were similar for both the medial and lateral pedicle impending breech positions prior to re-direction. A higher rate of vertebral body breaches occurred during redirection after a pedicle breach as compared to an impending pedicle breach (40\% vs $2 \%$ ), $\mathrm{p}<0.001$.

Review of the fluoroscopic documentation pedicle breaches occurred in 20 of 92 placements that were thought by the surgeons to be impending pedicle breeches. PediGuard with electronics had fewer pedicle breaches compared to PediGuard without electronics and standard Lenke probe (12.5\% vs $20 \%$ vs $33 \%), p=.1531$. When the results of the instruments were combined comparing electronics on vs no electronics, PediGuard had a pedicle breach rate of $12.5 \%$ compared to no electronics, $27 \%, p=0.1837$.
Overall analysis of all breeches considering "success" as no breach vs "failure" as occurrence of a breach, PediGuard with electronics had a success rate of $87 \%$ compared to PediGuard without electronics, $76 \%$ and the standard Lenke probe, $66 \%, p=0.1576$.

\section{DISCUSSION}

In part 1 of this study we wanted to test utility of the PediGuard to dynamically (in real time) prevent the surgeon from breaching the pedicle wall cortex or the vertebral body cortex before actually pushing the probe through the cortex during pedicle screw pilot hole preparation. "Successful" anticipation occurred in 65/ 75 drillings (87\%), where the PediGuard successfully warned the surgeon before a breach. Anticipation was less successful in the vertebral body groups 72 and $79 \%$ vs. the pedicle wall groups 100\%, most probably because of the cortical thickness. Anticipation occurs when the surgeon hears the sound change from a beep cadence consistent with cancellous bone to the slow cadence occurring with transition to cortical bone. The surgeon can stop at this point ("anticipation") before breaching the cortical wall.

The cortical wall in some of the vertebral bodies is so thin that either the surgeon could not tell the transition and accurately determine anticipation or the measurement from anticipation to breach was $\leq 1 \mathrm{~mm}$ upon advancing the probe. This issue of the vertebral body wall probably accounted for the 10 drillings (13\%) where the surgeon correctly detected a breach but not the anticipation. This is still a benefit clinically, as the surgeon dynamically knows he or she has breached (and probably wouldn't know with standard mechanical probe which became apparent in part 2 of the study. When the surgeon knows he has breached then earlier redirection of the drilling can be performed. The word "earlier" is used because the surgeon can just redirect the PediGuard probe instead of pulling the probe out, feeling with a ball point feeler and then putting the mechanical probe back in.

In part 2 of the study, we wanted to test the clinical scenario when once the surgeon knows there is an impending breach ("anticipation") within the pedicle wall then how successful is redirection of the probe advancing into the vertebral body? We wanted to test the utility of the PediGuard to dynamically (in real time) assist the surgeon in more successfully accomplishing this task. Successful redirection with the PediGuard with electronics ON was superior to PediGuard with electronics OFF and the standard Lenke probe (100\% vs. $90 \%$ vs. $79 \%, p=0.0191$ ). To further test the role of the electronics, when the results of the instruments were combined comparing electronics ON versus electronics OFF, PediGuard with electronics $\mathrm{ON}$ had a vertebral body breach rate upon redirection of $0 \%$ compared to electronics OFF $(16 \%, p=0.0243)$, which more strongly confirms the unique aspects of the PediGuard.

We further subanalyzed the data to review success of redirection if the redirection started after an anticipated breach (more common with PediGuard with electronics ON) versus an actual starting point for redirection when there is actually a breach of the probe (most commonly with electronics OFF or Lenke probe). A higher rate of vertebral body breaches occurred during redirection after a pedicle breach as compared to an anticipated pedicle breach (40\% vs $2 \%$, $p<0.001)$. This clinically suggests that the use of PediGuard can improve the surgeon's accuracy in placing a pedicle pilot hole in two major ways: (1) Anticipating a breach and knowing it, followed by (2) Better success in redirecting from an anticipated breach position as compared to a breached position.

This study had to be performed in a cadaver model, since it would be unethical to perform during actual clinical cases; therefore, no IRB approval for a human study was sought. The authors admit that the PediGuard device does not sound as crisp nor have as many clear distinctions of sound between bone density as in live bone during clinical surgery. Despite this limitation, accurate differentiating sounds between cancellous, cortex and breach can be made in this cadaver model. Extrapolation of these results to the clinical case suggests that the results would be even better for anticipation and redirection with the PediGuard. 
Pedicle screw insertion carries an inherent risk of breach of the pedicle wall and or vertebral body cortex which can range from 2.5 to $40 \%$. $^{5,8,9,11}$ Fortunately, most breaches are clinically insignificant but there are case series reporting revision rates for misplaced screws as high as 5.7\%.

In this cadaver study, using a probe with an electrical conductivity measurement tip (DSG) [PediGuard] anticipation of an impending cortical breach during placement of a pilot pedicle hole occurred in $80 \%$ of the drillings, with an additional $7 \%$ anticipated too soon by $1-2 \mathrm{~mm}$ before the breach actually occurred, for an $87 \%$ success rate. Sensitivity at the medial pedicle wall was $100 \%$. Use of the PediGuard may significantly reduce pedicle screw breach when using a manual technique for drilling/probing.

Successful redirection by passing the curved pedicle probes into the vertebral body without a breach after anticipation of an impending pedicle wall breach occurred in $100 \%$ of the drillings when done with the SG with the electronics ON vs only $84 \%$ with electronics OFF ( $p=0.0243)$.

\section{CONCLUSION}

Anticipation of an impending cortical breach during placement of a pilot pedicle hole using PediGuard occurred in $87 \%$ of the drillings. Successful redirection by passing the pedicle probes in to the vertebral body without a breach after anticipation of an impending pedicle wall breach occurred in all of the drillings when done with the PediGuard with electronic on.

Conflict of interest: The authors act as consultants on behalf of Pediguard.

\section{REFERENCES}

1. Burton DC, Asher MA, Lai SM. Scoliosis correction maintenance in skeletally immature patients with idiopathic scoliosis. Is anterior fusion really necessary? Spine (Phila Pa 1976). 2000;25(1):61-8

2. Hackenberg $L$, LinkT, Liljenqvist $U$. Axial and tangential fixation strength of pedicle screws versus hooks in the thoracic spine in relation to bone mineral density. Spine (Phila Pa 1976). 2002:27(9):937-42.

3. Kim YJ, Lenke LG, Bridwell KH, Kim KL, Steger-May K. Pulmonary function in adolescent idiopathic scoliosis relative to the surgical procedure. J Bone Joint Surg Am. 2005:87(7):1534-41.

4. Liljenqvist $U$, Lepsien $U$, Hackenberg L, Niemeyer T, Halm H. Comparative analysis of pedicle screw and hook instrumentation in posterior correction and fusion of idiopathic thoracic scoliosis. Eur Spine J. 2002;11(4):336-43.

5. Suk SI, Lee CK, Kim WJ, Chung YJ, Park YB. Segmental pedicle screw fixation in the treatment of thoracic idiopathic scoliosis. Spine (Phila Pa 1976). 1995;20(12):1399-405.

6. Suk SI, Lee CK, Min HJ, Cho KH, Oh JH. Comparison of Cotrel-Dubousset pedicle screws and hooks in the treatment of idiopathic scoliosis. Int Orthop.1994;18(6):341-6.

7. Yahiro MA. Comprehensive literature review. Pedicle screw fixation devices. Spine (Phila

Pa 1976). 1994;19(Suppl 20):2274S-2278S

8. Liljenqvist UR, Halm HF, Link TM. Pedicle screw instrumentation of the thoracic spine in idiopathic scoliosis. Spine (Phila Pa 1976). 1997:22(19):2239-45.

9. Suk SI, Kim WJ, Lee SM, Kim JH, Chung ER. Thoracic pedicle screw fixation in spinal deformities: are they really safe? Spine (Phila Pa 1976). 2001;26(18):2049-57.

10. Donovan DJ, Polly DW Jr, Ondra SL. The removal of a transdural pedicle screw placed for thoracolumbar spine fracture. Spine (Phila Pa 1976). 1996;21(21):2495-8.

11. Papin $P$, Arlet $V$, Marchesi $D$, Rosenblatt $B$, Aebi M. Unusual presentation of spinal cord compression related to misplaced pedicle screws in thoracic scoliosis. Eur Spine J. 1999;8(2):156-9

12. Yalçin $S$, Güven $O$. Reversible anterior cord syndrome due to penetration of the spinal canal by pedicular screws. Paraplegia. 1995;33(7):423-5.

13. Jendrisak MD. Spontaneous abdominal aortic rupture from erosion by a lumbar spine fixation device: a case report. Surgery. 1986;99(5):631-3.

14. Bolger C, Brayda-Bruno M, Kaelin A, Kaelin A, Lazennec JY, Le Huec JC, et al. A new device to detect iatrogenic initial vertebral cortex perforation: first clinical results [abstract]. Eur Spine J. 2003;12(Suppl 1):1-79. 